\title{
Prediction of death anxiety based on emotional self-regulation and self- efficacy in cancer patients
}

\author{
Taimour Khamoshi Darmarani ${ }^{1}$, Omid Moradi ${ }^{2}$ \\ 1-M.A, Clinical Research Development Center, Taleghani and Imam Ali Hospitals, Kermanshah University of \\ Medical Sciences, Kermanshah, Iran . \\ 2- Assistance Professor, Department of Psychology, Sanandaj Branch, Islamic Azad University, Sanandaj, Iran \\ (Corresponding Author). $\quad$ E-mail: moradioma@gmail.com
}

Received: 01/11/2019

Accepted: 20/01/2020

\begin{abstract}
Introduction: Death anxiety can be one of the important psychological diagnoses in cancer patients.

Aim: The peresent study aimed at predicting death anxiety based on emotional self-regulation and self-efficacy in cancer patients.

Method: This is a descriptive correlational study. The statistical population included all of cancer patients in Kermanshah city in the years 2019. A sample of 150 cancer patients were randomly selected. Measurement tools included death anxiety questionnaire, Gross and John emotional self-regulation questionnaire, Scherrer self-efficacy questionnaire. To analyze the data, Pearson correlation coefficient and Concurrent regression were used.
\end{abstract}

Results: The results showed that there is no significant relationship between emotional selfregulation and death anxiety $(\mathrm{P}=0.29, \mathrm{R}=-0.087)$. But there is a significant inverse relationship between self-efficacy and death anxiety $(\mathrm{P}<0.001)$. Although The results of regression analysis showed that emotional self-regulation and self-efficacy predict $15 \%$ of the variance of the death anxiety variable.

Conclusion: Based on the findings in this study, it is necessary to emphasize these psychological characteristics in educational, prevention and treatment programs in hospitals.

Keywords: Death anxiety, Emotional self-regulation, Self-efficacy, Cancer

How to cite this article : Khamoshi Darmarani T, Moradi O. Prediction of death anxiety based on emotional self-regulation and self-efficacy in cancer patients. Shenakht Journal of Psychology and Psychiatry. 2020; 6 (6): 66-76 .URL: http://shenakht.muk.ac.ir/article-1-816-fa.pdf

Copyright $\odot 2018$ the Author (s). Published by Kurdistan University of Medical Sciences. This is an open access article distributed under the terms of the Creative Commons Attribution-Non Commercial License 4.0 (CCBY-NC), where it is permissible to download, share, remix, transform, and buildup the work provided it is properly cited. The work cannot be used commercially without permission from the journal. 


\section{بيشبينى اضطراب مر تى بر اساس خودتنظيمى هيجانى و خودكار آمدى در بيماران سرطانى}

تيمور خاموشى درمرانى '، اميد مرادى

ا.كارشناسى ارشد ، مركز توسعه تحقيقات بالينى ايت ا... طالقانى و امام على (ع)، دانشگاه علوم يزشكى كرمانشاه، كرمانشاه، ايران. r. استاديار، گروهه روانشناسى، واحد سنندج، دانشگاه آزاد اسلامى، سنندج، ايران (مولف مسئول). ايميل: moradioma@gmail.com

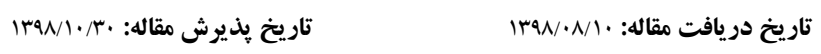

\section{جكيده}

مقدمه: اضطر اب مركى مى تواند به عنوان يكى از تشخيصهاى مهم روانشناختى در بيماران مبتلا به سرطان مطرح باشد. هدف: يزوهش حاضر با هدف بيشبينى اضطراب مركى بر اساس خودتنظيمى هيجانى و خودكار آمدى در بيماران سرطانى انجام كرفت.

روش: بزوهش حاضر توصيفى و از نوع همبستكى است. جامعه آمارى يزوهش شامل بيماران سرطانى شهر كرمانشاه در سال 1هبا

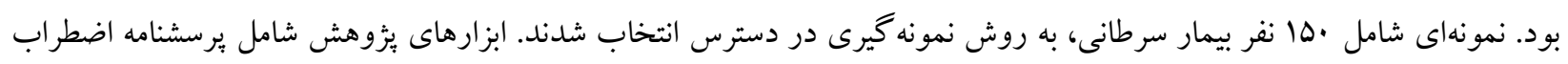

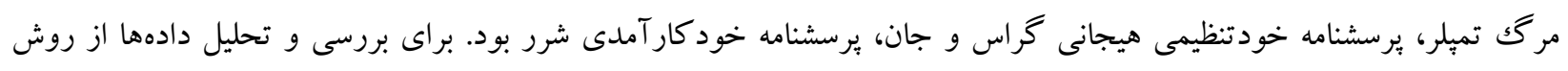
همبستخى بيرسون و ركر سيون همزمان استفاده شد.

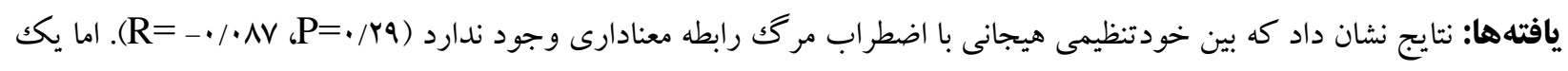

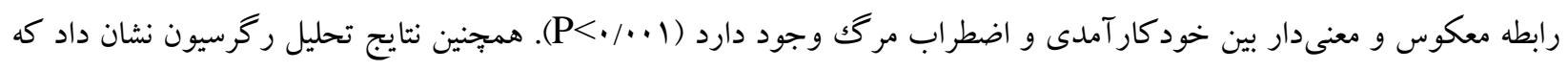

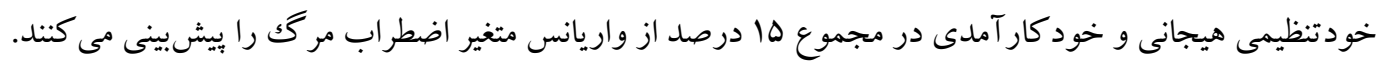

نتيجه كيرى: با توجه به يافتهاى بثزوهش، ضرورى است در برنامهاى آموزشى، بيشخيرى و درمانى در بيمارستانها، بر اين ويز گیى هاى روانشناختى تأكيد گردد. كليدوازهها: اضطر اب مر گ، خودتنظيمى هيجانى، خود كار آمدى، سرطان 
بيماران معطوف است، در حالى كه با بيشرفت بيمارى و علائم مرتبط با آن، بيماران از درد، رنج، تنهايى، تنبيه و كاهش كنترل مى ترسند كه همخى اينها به عنوان ابعاد

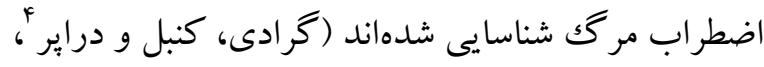

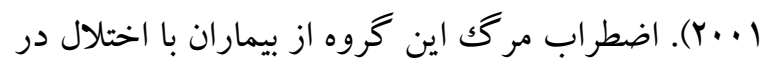
بعد روانى و حتى روحى مىتواند كيفيت زندگى آنان را تحت تأثير قرار دهد؛ بنابراين تشخيص و و شنى روناسايى مؤلفه هايى كه ممكن است بر كيفيت زندگى بيماران مبتلا به سرطان تأثير داشته باشد، حائز اهميت است (هولزنرها

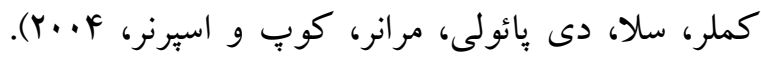
يكى از مفاهيمى كه به اضطراب بخصوص اضطراب

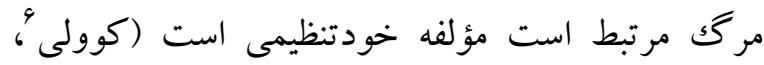

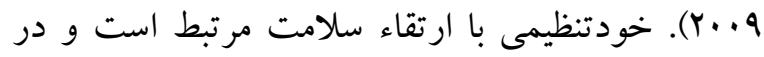
كنترل سلامت روان اهميت ويزهاى دارد؛ از اين رو مى توان خودتنظيمى را عاملى مؤثر بر سلامت فرد در نظر

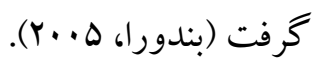

خودتنظيمى به عنوان كوششهاى روانى در كنترل وضعيت درونى، فرايندها و كاركردها براى دستيابى به اهداف بالاتر تعريف شده است (كارى، غفارى، نوران و

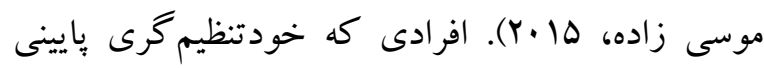
دارند از احساسات خود كم بينى رنج مىبرند و از عدم موفقيت و از دست دادن كنترل واهمه دارند (هاشمى و

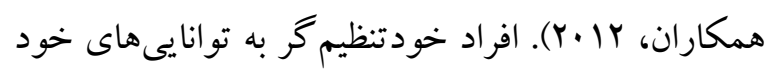

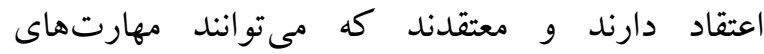
فراشناختى مورد نياز براى استفاده از اين راهبردها و

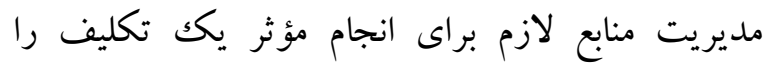

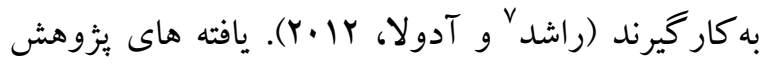

مقدمه

در حال حاضر سرطان يكى از مسائل مهم بهداشتى درمانى جهان و نيز كشور ما محسوب مىشود. بر اساس تمام شواهد علمى، تجربى و ئزوهشى، اين بيمارى در رديف اساسىترين و خطرناككترين بيمارىهاى مزمن و از عوامل تهديدكننده جامعه به شمار مىرود (زمان،

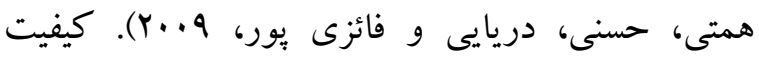
زندگى در بيماران مبتلا به سرطان تنها با بيمارى و درمان آن تعيين نمىشود بلكه وابسته به ساير وضعيتهاى يزشكى و مشخصات فردى و اجتماعى است. مفاهيمى از قبيل سلامت جسمانى، وضعيت روانى، اعتقادات فردى، روابط اجتماعى و ارتباط فرد با محيط از طرق مختلف، از جمله مواردى است كه بر كيفيت زندگى تأثير مى گذارند

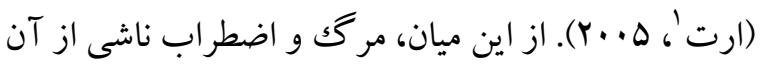
به عنوان يكى از مهم ترين مؤلفههاى سلامت روانى افراد

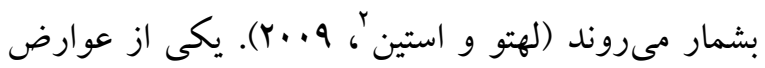
شايع روانى، اضطراب و به ويثه اضطراب مر گك است. اين نوع اضطر اب مىتواند به عنوان يكى از تشخيص هاى مهم روانشناختى در بيماران مبتلا به سرطان مطرح باشد. اين نوع اضطراب، ترس مداوم، غيرطبيعى و مرضى از مركّ يا مردن است. اين مفهوم به مرگك هراسى (ترس از مرگك)

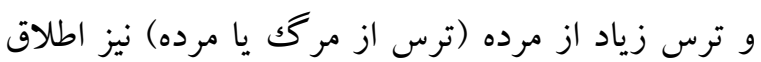

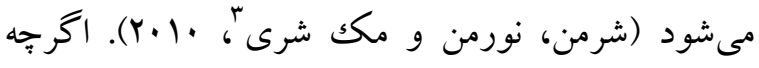
ترس از مرگك و مردن ممكن است عمومى باشد اما افراد در ابراز واكنش هاى احساس نسبت به آن متفاوت هستند. در اغلب موارد توجه تيم درمان بيشتر بر تثبيت علائم فيزيكى و جسمانى (تسكين درد، تهوع، استفراغ و...)

\footnotetext{
1. Oort

2- Lehto \& Stein

3 - Serman,Norman \& McSherry
}

5 - Holzner, Kemmler, Cella, DePaoli, Meraner, Kopp \& Sperner

7- Rasheed \& Adeola 
ديابتى بيش بينى مى كند. يافتهاى جكك و همكارانج نشان داد كه بين خودكارآمدى، اضطراب و و (Y.IV) كيفيت زندگى رابطه معنادارى وجود دارد و و خودكارآمدى بايد يك جزء كليدى از برنامه هاى روانشناختى طراحى شده براى حمايت از بيماران مبتلا به سرطان در سراسر شيمى درمانى باشد. به رغم اينكه در

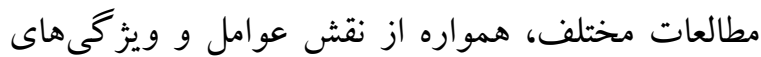
فردى در شروع و تداوم اضطراب مرك بحث شده است،

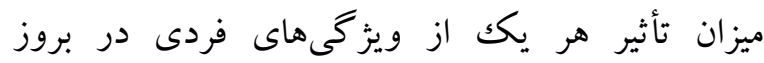
اضطراب مركى نامشخص است، با توجه به اينكه در زمينه شناخت بيشايندها و عوامل زمينه ساز و دخيل در اضطراب مركى در كشورمان مطالعات كمى صورت يذيرفته است، در اين ثُروهش درصدد برآمديم تا به بررسى برخى متغيرهايى بيردازيم كه ممكن است بتواند

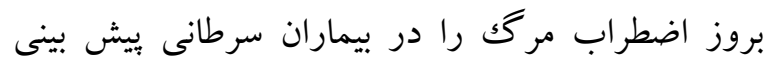
كندا؛ بنابراين يثوهش حاضر با هدف بيش بينى اضطراب مركى در بيماران سرطانى با استفاده از دو متغير بنائن خودتنظيمى هيجانى و خود كار آمدى انجام كرفته است.

روش

روش تحقيق، توصيفى و از نوع همبستخى است. جامعه آمارى اين يُروهش شامل كليه افراد داراى بيمارى سرطان در بيمارستان آيت اله طالقانى شهر كرمانشاه در سهماهه

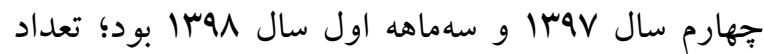
دقيق آنها طبق آخرين آمار از سوى كارشناس واحد

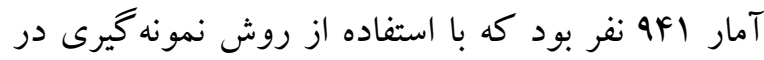

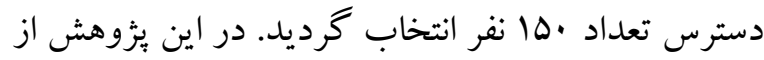
سه نوع ابزار براى سنجش متغيرها استفاده شد.
ميرهاشمى و تو كلى (1/) نشان داد كه بين شاد كامى و خودتنظيمى هيجانى و تنظيم هيجانى شناختى رابطه معنادارى وجود دارد و //ه درصد از واريانس شادكامى توسط خودتنظيمى هيجانى و تنظيم هيجانى شناختى بيش بينى مى شود. همجنين يافته هاى بتول و همكاران'

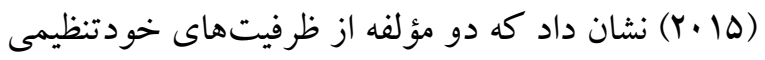
يعنى تعديل روانشناختى و سلامت جسمى با كيفيت زندكى در بيماران ديابتى رابطه دارند. از ديخر از مفاهيم روانشناختى كه با اضطراب مركك مربوط است، متغير خود كار آمدى است. خود كار آمدى از متغيرهاى كليدى

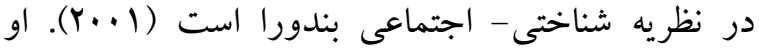

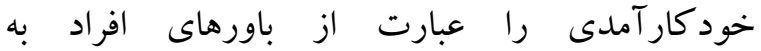
توانايىهايشان در بسيج انخيزهها، منابع شناختى و اعمال كنترل بر يكك رخداد معين تعريف كرده است (بندورا،

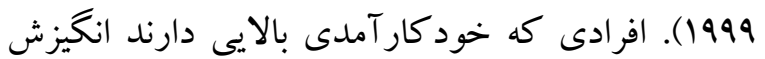
بالاترى دارند و معتقدند كه مىتواند مهارتهاى

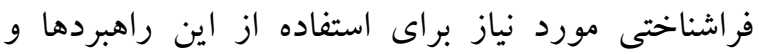
مديريت منابع لازم براى انجام مؤثر يكك تكليف را به كار بندند و فرايند انجام كار را تحت نظارت خود در آورند؛ اما افرادى كه خود كار آمدى بايينى دارند و به تو انايىهاى

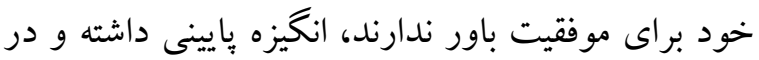
شروع و به انجام رساندن تكليف تأخير نشان مىدهند

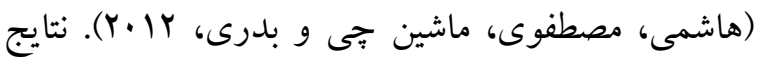

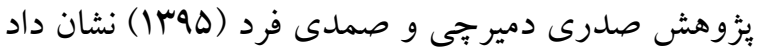
كه بين خودكارآمدى و عزت نفس با اميد به زندكى صنى بيماران ديابتى رابطه معنادارى وجود داشت و خودكارآهدى، عزتنفس و حمايت اجتماعى ادراكك شده در مجموع هه درصد اميد به زندگى را در بيماران 
آشكار استفاده شد كه نتيجه Fץ/ همبستگى را نشان

ابزار

مى دهل.

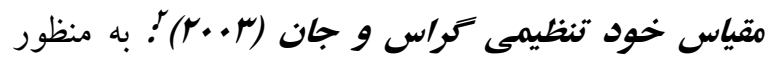

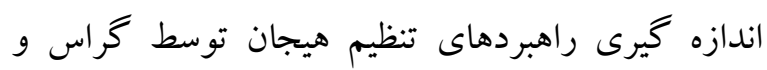

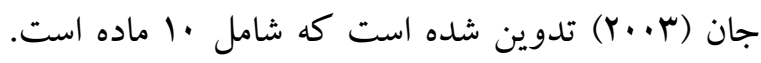
اين برسشنامه مشتمل بر دو خرده مقياس ارزيابى مجدد

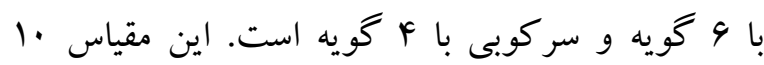
آيتمى جهت ارزيابى تمايل افراد به تنظيم هيجانات به دو طريق زير تهيه شده است: ارزيابى مجدد شناختى و بازدارى بيانكر. باسخها به هر آيتم در مقياس ليكرت آيتمى از ا (به شدت مخالفم) تا V (به شدت موافقم) قرار كرفتهاند. نتايج يثروهش بايايى مناسبى را براى اين آزمون كزارش كردند (آلفاى كرونباخ ارزيابى مجدد بازدارى بيانكر س/•). همجنين اعتبار آزمون-آزمون مجدد در طول سه ماه براى هر دو مؤلفه اين يرسشنامه

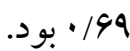

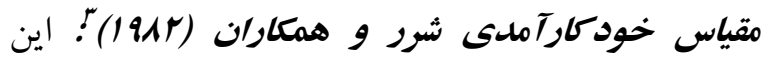
يرسشنامه توسط شرر و همكاران (191Y) ساخته شده است كه شامل IV ماده است. شرر و مادو كس مشخص كردن عوامل و عبارات آنها معتقدند كه اين مقياس سه جنبه از رفتار شامل ميل به آغازگرى رفتار، ميل به كسترش، تلاش براى كامل كردن تكليف و متفاوت در رويارويى با موانع را اندازهيرى مى كند. اين مقياس داراى IV سؤال است كه هر سؤال بر اساس مقياس ليكرت از دامنه كاملاً مخالفم تا كاملاً موافقم تنظيم مىشود. نمره كذارى مقياس به اين صورت است كه به هر

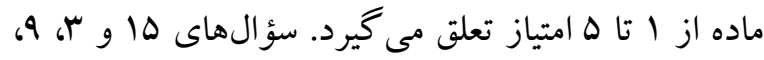

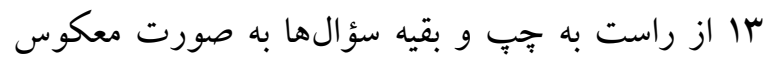

2- Gross \& John

${ }^{3}$ - Sherer, Maddux, Mercandante, Prentice-Dunn, Jacobs \& Rogers
در اين يُوهش از سه بِرسشنامه اضطراب مركَ تميلر، برسشنامه خودتنظيمى هيجانى گراس و جان و وبرسشنامه خود كار آمدى شرر و همكاران استفاده شد. مقياس اضطراب مركى تمبلر (19V.) '؛ مقياس اضطراب مركَ تميلر ابزارى براى اندازهگيرى اضطراب مربوط به له

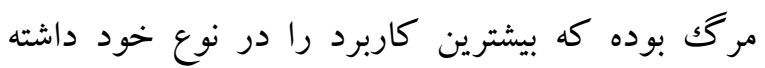
است. اين مقياس، برسشنامهاى خوداجرايى متشكل از وانزده سؤال بلى - خير است. اين برسشنامه توسط رجبى و

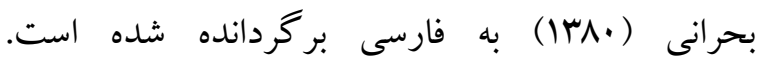

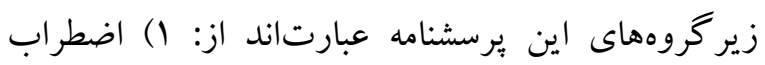

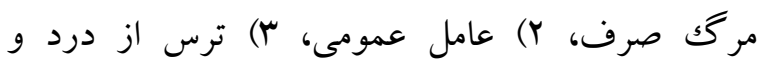
جراحى. در اين برسشنامه پياسخ بلى نشانه وجود اضطراب در فرد است. دامنه نمرههاى اين مقياس از صفر تا پانزده

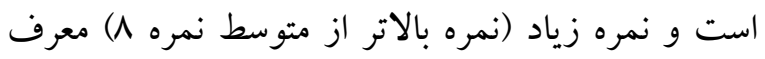
درجه بالايى از اضطراب مركى است. به اين ترتيب نمرههاى اين مقياس بين صفر تا يانزده متغير است كه نمره

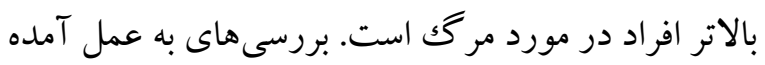
درباره اعتبار مقياس اضطر اب مركى، نشان مىدهد كه اين مقياس از اعتبار قابل قبولى بهرهمند است، ضرايب آلفاى كرونباخ را براى عاملهاى سه گانهاى كه با روش تحليل عوامل و ويرايش ايتاليايى اين مقياس به دست آمدهاند،

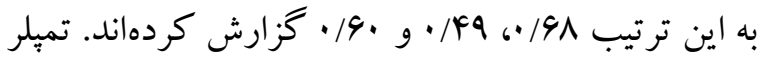
(19V.) ضريب باز آزمايى مقياس را سA/· به دست آورده است. همجِنين يايايى برسشنامه در بُزوهش قاسم

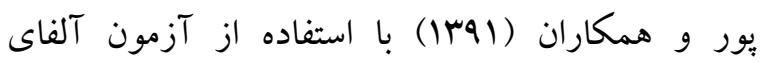
كرونباخ 90\% به دست آمده است. در يُوهش رجبى و

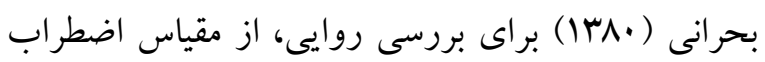

\footnotetext{
1- Templer
} 


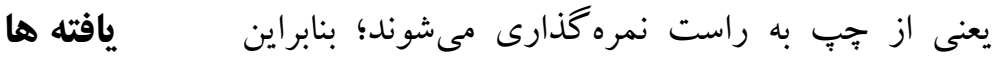

نرم افزار مورداستفاده در اين ثئوهش SpSS نسخه

بود. با توجه به يافتهاى توصيفى مشخصات دمو گر افيكى موردي شر كت كنند گان ميانگين سنى بيماران سرطانى افراد بين IV-AY

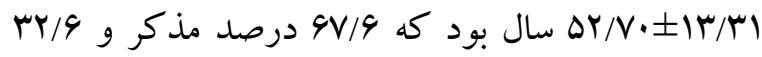

$$
\text { درصد مؤنث بودند. }
$$

F دييلم، /// درصد ليسانس و \&/ • درصد كارشناس ارشد و بالاتر بودند. سم/V/ درصد مجرد، سم/1 د درصد متأهل و س// درصد مطلقه بودند. در جدول I آمارهاى تو صيفى متغيرهاى مورد بُزوهش آمده است.
حداكثر نمرهاى كه فرد مىتواند از اين مقياس به دست آورد همرو حداقل نمره IV است. اين مقياس توسط براتى

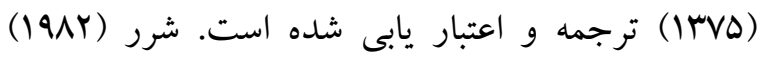
اعتبار محاسبه شده از طريق آلفاى كرونباخ براى

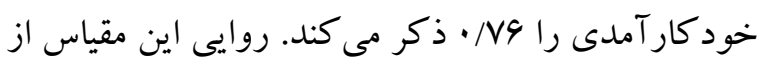
طريق روايى سازه به دست آمده است. در يزوهشى كه به منظور بررسى اعتبار و روايى اين مقياس، توسط براتى

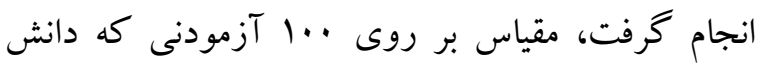
آموز سوم دبيرستان بودند اجرا شد؛ همبستگى (191 •) به دست آمده از Y مقياس عزت نفس و خودارزيابى با مقياس خودكار آمدى در جهت تأييد روايى سازه اين مقياس بود (اعرابيان، سمبا).

\begin{tabular}{|c|c|c|}
\hline انحر اف معيار & ميانكين & متغير \\
\hline N/91 & $r \Delta / q v$ & خودتنظيمى \\
\hline N/VD & $q T / Y q$ & خود كار آمدى \\
\hline$r / 11$ & 9191 & اضطراب مركى \\
\hline
\end{tabular}

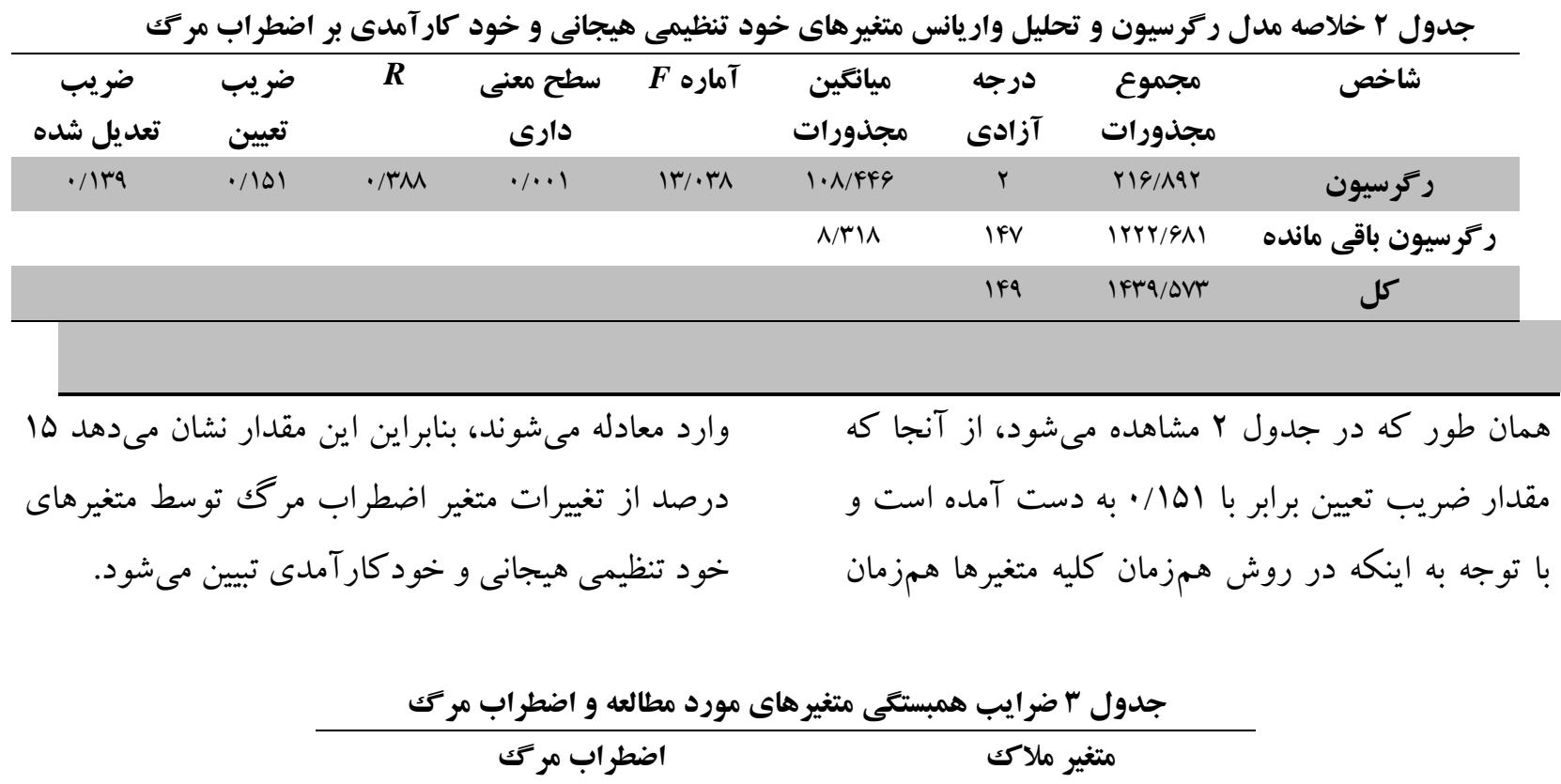




\begin{tabular}{|c|c|c|}
\hline سطح معنادارى & ضريب همبستىى & متغير هيش بين \\
\hline$\cdot / 49$ & $-\cdot / \cdot \wedge \mathrm{V}$ & خودتنظيمى هيجانى \\
\hline$<\cdot / \cdot \cdot 1$ & $-\cdot /$ rAD & خود كار آمدى \\
\hline 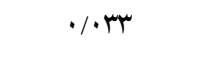 & $-\cdot /$ IVF & ارزيابى مجددشناختى \\
\hline . /NFG & $\cdot / \cdot \mathrm{VA}$ & بازدارى بيانكر \\
\hline$<\cdot / \cdot \cdot 1$ & $-\cdot /$ r I I & ميل به آغاز كرى \\
\hline$<\cdot / \cdot \cdot 1$ & $-\cdot /$ TVQ & تفاوت در رويارويى با موانع \\
\hline$\cdot / \cdot v$ &.$- / 1 \% 9$ & ميل به كسترش براى كامل شدن \\
\hline
\end{tabular}

يخوهش حاضر با هدف ييشبينى اضطراب مركى بر اساس خودتنظيمى هيجانى و خود كارآمدى در بيماران

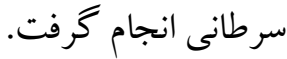

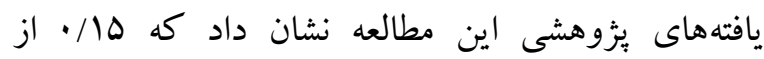

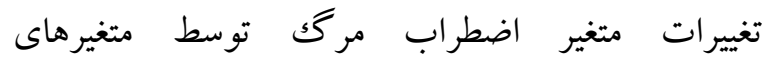
خود تنظيمى هيجانى و خود كار آمدى بيش بينى مىشود. يافتهاى يُزوهش حاضر در اين زمينه با يافتهاى صمدى

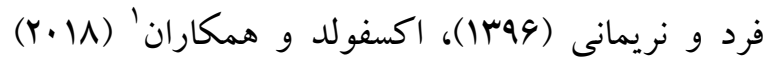
همسو است. كرد و سامانى (99 I ا) نشان دادند كه بين ذهن آكاهى و باورهاى غيرمنطقى با اضطراب مرگك رابطه معنادارى وجود داشت. تفاوتى كه بين يثزوهشهاى ييشين و بثزوهش حاضر وجود دارد، تفاوت در تمركز بر متغيرهاى بُزوهش است. همجنين، ابزارهاى مورد استفاده در يُزوهش هاى بيشين با بُزوهش حاضر متفاوت بود. با اين حال، از حيث هدف با بزوهشهاى بيشين داراى همسويى است. يافتهاى يخوهش كوياى آن است كه در

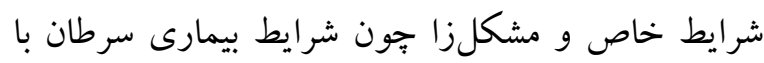
توجه به سطوح بالاى استرس و هراس، فرد كاه دست به رفتارهاى مقابلهاى ناكار آمد و ناساز كار مى زند كه در بر اين ميان نگرش منفى به اضطراب مركَ قابل تصور است

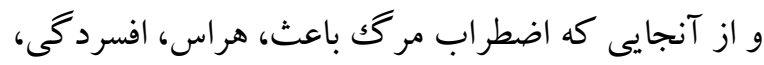

جدول ץ نشان دهنده ضريب همبستگى بين خودتنظيمى هيجانى و اضطراب مرگك است. همانطور كه مشاهده مىشود، بين خودتنظيمى هيجانى با اضطراب مركى رابطهى معنادارى وجود ندارد (r=//AV ميان مؤلفههاى خودتنظيمى هيجانى و اضطراب مركّ، فقط بين مؤلفه ارزيابى مجددشناختى ارتباط معنىدارى و از نوع معكوس وجود دارد (سM+/• طورى كه با افزايش نمرههاى اين مؤلفه، اضطراب مرك

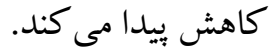
همانطور كه از جدول ب مشاهده مىشود نتايج نشاندهنده وجود يكك رابطه معكوس و معنىدار بين

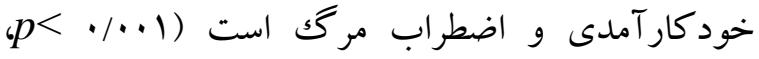
ه/r/• خود كار آمدى، اضطراب مرگك كاهش بيدا مى كند. ميان

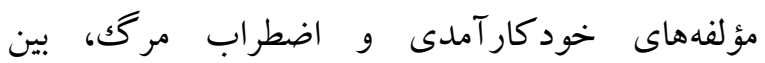
مؤلفه هاى ميل به آغاز گرى (1)

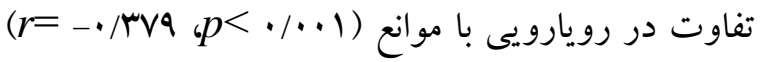
ارتباط معنىدار و از نوع معكوس وجود دارد. بهطورى كه با افزايش نمرههاى اين مؤلفها، اضطراب مركَ كاهش

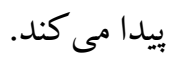

\section{Scheffold \& Et al}


بيمارى سرطان دجار اضطراب مرك مى شوند؛ بنابراين مى توان نتيجه گرفت كه به ميزانى كه يك فر فرد از خود تنظيمى هيجانى بالايى برخوردار باشد، قادر به كنترل

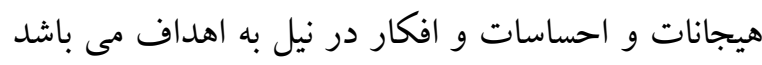

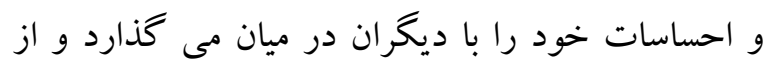
احساس خود كم بينى و تنهايى رنج نمى برد. همجنين اين كونه افراد گرايش كمترى به اضطراب مر گك دارند. همجنين نتايج بيشتر نشان داد كه يك رابطه غيرمستقيم

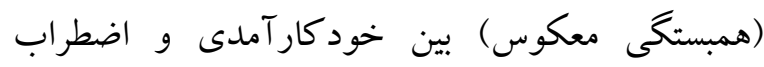
مركَ وجود دارد و معنىدار است؛ يعنى با افزايش جهت گيرى خود كار آمدى، اضطراب مركى كاهش بيدا مى كند. همجِين يافتها نشان مىدهد كه ميان مؤلفههاى خود كار آمدى و اضطراب مرگك، بين مؤلفههاى ميل به يه آغازگرى و تفاوت در رويارويى با موانع ارتباط

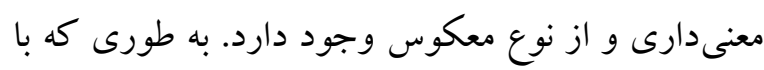
افز ايش نمرههاى اين مؤلفهها، اضطراب مر گك كاهش بيدا مى كند؛ و مى توان كفت كه متغير خود كار آمدى توان ييشبينى اضطراب مركى را دارد و با يزوهش هاى

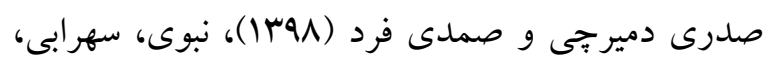

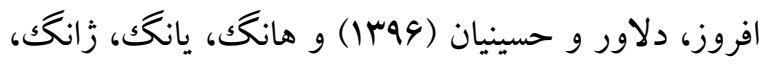

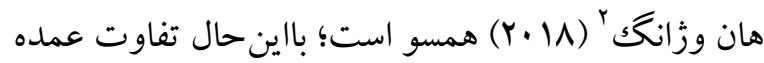
از حيث هدف است. يثوهش حاضر با هدف بيش بينى اضطراب مرگك در بيماران سرطانى با توجه به متغير خودتنظيمى هيجانى و خود كار آمدى صورت گرفت. در حالى كه ئزوهشهاى يِيشين با هدف بيش بينى اميد به زندكى و سلامت روان بر اساس خود كار آمدى صورت كرفته بود. در تبيين يافته ها مىتوان استنباط كرد كه خود كار آمدى مى تو اند به عنوان يكى از مؤلفههاى مهم
رنج، تنهايى، احساس گناه در فرد مىشود و براى كنار آمدن با آنها فرد نيازمند داشتن توان بالاى مقابلهاى است كه در بعضى افراد وجود ندارد، لذا سبب آسيبهاى خاص از جمله اضطراب مركى مى شود. يافتها نشان داد كه بين خودتنظيمى هيجانى و اضطراب مرگك رابطه معنادارى وجود ندارد؛ اما ميان مؤلفهاى خودتنيمى هيجانى و اضطراب مرگك، فقط بين مؤلفه ارزيابى مجدد شناختى ارتباط معنىدارى و از نوع معكوس وجود دارد، به طورى كه با افزايش نمرههاى اين مؤلفه، اضطراب مرگك كاهش بيدا مى كند. يافتهاى يثزوهش حاضر در اين فرضيه با بزوهشهاى صابرى فرد و

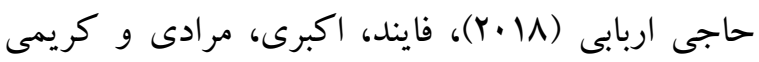
(Y.11)

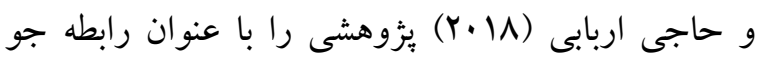
عاطفى خانو اده با خود تنظيمى هيجانى و تاب آورى انجام دادند. آنها در بثوهش خود كزارش كردند كه جو عاطفى خانواده با خودتنظيمى هيجانى رابطه معنادارى دارد. تفاوتى كه بين يزٔوهش حاضر و يزٔوهشهاى بيشين وجود دارد، ئزوششاى بيشين بر روى سالمندان و بيماران غير سرطانى انجام گرفته است. در حالى كه اين يثزوهش اضطراب مرگك را در افراد داراى بيمارى سرطان مورد بررسى قرار داده است و نشان دهنده نوآورى اين يثزوهش است. در تبيين اين يافته ها مى توان كفت كه افراد با خودتنظيمى هيجانى پِيين توانايى كنترل احساسات، افكار و هيجانات خود در جهت اهداف موردنظر را به نحو مطلوبى ندارند و از احساس خود كم بينى رنج مى برند و توانايى ساز گارى بايينى در برابر مشكلات دارند و در شرايط خاص و مشكل زا جون بـاني 
مطالعه حاضر مستخرج از بايان نامه كارشناسى ارشد با

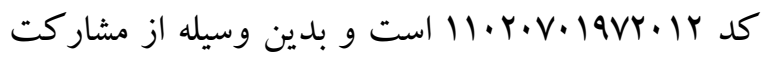
بيماران محترم سرطانى و همجنين از عوامل اجرايى بيمارستان حضرت آيت اله طالقانى شهرستان كرمانشاه

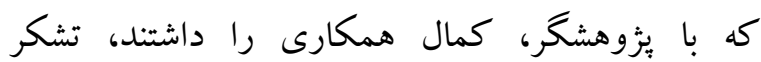
مىنما ييم.

\section{References}

Akbari BA. (2014). Simple and multiple relationship between self-efficacy, achievement goals, and achievement motivation in predicting academic achievement among students of Semnan University of Medical Sciences. (In Persian).

Arabian A, Khodapanahi MK, Heydari M, \& SALEH SB. (2005). Relationships between self efficacy beliefs, mental health and academic achievement in colleagues.

Bandura A, Pastorelli C, Barbaranelli C, \& Caprara GV. (1999). Self-efficacy pathways to childhood depression. Joumal of Personality and social Psychology, 76(2), 258.

Bandura A. (2001). Social cognitive theory: An agentic perspective. Annual review of psychology, 52(1), 1-26.

Bandura A. (2005). The primacy of self-regulation in health promotion. Applied Psychology, 54(2), 245-254.

Batool A, MalikJA, \& Nawaz A. (2015). Relationship between self-regulation and quality of life: an intensive exploration in patients with diabetes. International Journal of Diabetes in Developing Countries, 35(2), 275-283.

Bohlmann NL, \& Downer JT. (2016). Self-regulation and task engagement as predictors of emergent language and literacy skills. Early Education and Development, 27(1), 18-37.

Fard FS, \& Hajiarbabi F. (2018). The relationship between family emotional climate with emotional self-regulation and resilience in university's student. (In Persian).
شخصيتى نقش مهمى در برابر مشكلات و فشارهاى

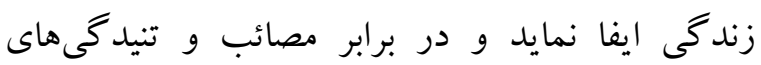
زندگىى، افراد جقدر تلاش نموده و در برابر آنها تاب آورى نشان دهد؛ و كمتر دجار اضطراب و اضطراب

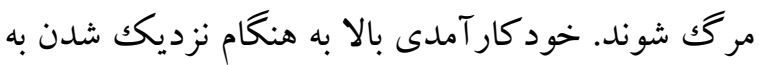
كار و كنشهاى دشوار، به ايجاد احساس آسانى و موفقيت كمكك مى كند و اين موفقيتها منجر به شكل گيرى باورهاى قوى در مورد كار آمدى شده و

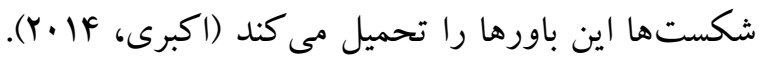

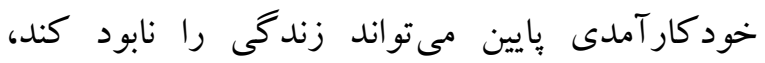
آرزوها را كم كند، با توانايى هاى شناختى تداخل نمايد و تأثير نامطلوبى بر سلامت جسمانى بخذارد (ريان' و و ديسى، · ( · Y)؛ بنابر اين مى توان خود كار آمدى را به عنوان يكك عامل كه توان بيش بينى اضطراب مركَ را دارد در

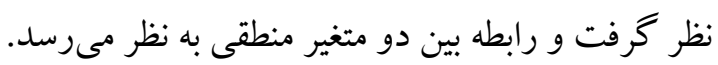

\section{نتيجه كيرى} نتايج يافته هاى اين بزوهش در زمينه اين كه متغيرهاى خودتنظيمى هيجانى و خود كار آمدى توان بيشينى متغير اضطراب مرگك را دارند، نشان داد كه خودتنظيمى هودي هيجانى و خود كار آمدى موجب كاهش اضطراب مركى مىشوند، لذا توصيه مىشود براى بيماران سرطانى برنامهاى آموزشى جهت افزايش خودتنظيمى هيجانى و خود كار آمدى فراهم شود تا سبب ارتقاء بهداشت روان آنها گردد. نتايج اين برّوهش مرتبط به بيماران سرطانى استان كرمانشاه مىباشد كه واجب است، در تعميم نتايج

$$
\text { به ديخر استان ها احتياط شود. }
$$

سياسگز ارى

\footnotetext{
1- Ryan \& Deci
} 
Fayand J, Akbari M, Moradi O, \& Karimi, K. (2018). The Effectiveness of Emotional SelfRegulatory Model on Improving the Quality of Life in Multiple Sclerosis Patients. Joumal of Health and Care, 20(4), 301-311. (In persian).

Gh R, \& Bohrani M. (2001). Factorial analysis of death anxiety scale. Psychol J, 4(20), 331-344.

Ghasempour A, Sooreh J, \& Kand MTST. (2012). Predicting death anxiety on the basis of emotion cognitive regulation strategies. Knowledge and Research in Applied Psychology, 13(2), 63-70.

Grady PA, Knebel AR, \& Draper A. (2001). End-oflife issues in AIDS: the research perspective. Journal of the Royal Society of Medicine, 94(9), 479-482.

Gross JJ, \& John OP. (2003). Individual differences in two emotion regulation processes: implications for affect, relationships, and wellbeing. Joumal of personality and social psychology, 85(2), 348.

Hashemi T, Mostafani F, Mashinchi AN, \& Badri R. (2012). Role of goal orientation, self-efficacy of self-regulation and personality in procrastination. (In Persian).

Holzner B, Kemmler G, Cella D, De Paoli C, Meraner V, Kopp M, \& Spemer-Unterweger B. (2004). Normative data for functional assessment of cancer therapy general scale and its use for the interpretation of quality of life scores in cancer survivors. Acta Oncologica, 43(2), 153-160.

Huang FF, Yang Q, Zhang J, Han XY, \& Zhang JP. (2018). The structural equation model on selfefficacy during post-op rehabilitation among non-small cell lung cancer patients. PloS one, 13(9), e0204213.

Irrational Beliefs Samadifard H, \& Narimani M. (1396). Prediction of Death Anxiety of Elderly Based on Mindfulness and. (In Persian).

Jackie McBride BSc Hons RN, Zoe Polly BSc Hons RN, Simon Bettles BSc Hons RN, \& Alison Whitehouse BSc Hons RN. (2017). Patientreported self-efficacy, anxiety, and healthrelated quality of life during chemotherapy: results from a longitudinal study. In Oncology nursing forum (Vol. 44, No. 1, p. 127). Oncology Nursing Society.

Kari F, GhafariNouran O, \& Moosazade T. (2015). On the Comparison of Self-Perception, Emotional Self-Regulation, and Attachment Styles between Normal People and Drug-Dependent People. Research on Addiction, 8(32), 105117. (InPersian).

Koole SL. (2009). The psychology of emotion regulation: An integrative review. Cognition and emotion, 23(1), 4-41.

Kurd N, \& Samani S. (2017). prediction of deat anxiety based on welfare gloria and ratio offectum A Deum women senes. (In Persian).

Lehto R, \& Stein K. (2009). Death anxiety: an analysis of an evolving concept.

MirHashimi M, \& Tavakoli Z (2015). Predicting happiness based on emotion regulatin and Self-regulaetion con Ference on psyckology and Behavioral Scinces-Tehran,Narkish Institute. (In Persian).

Nabavi S, Sohrabi F, Afrouz G, Delavar A, \& Hosseinian S. (2017). Predicting the Mental Health of Teachers Based on the Variables of Self-Efficacy and Social Support. Health Education and Health Promotion, 5(2), 129138. (InPersian).

Oort FJ. (2005). Using structural equation modeling to detect response shifts and true change. Quality of Life Research, 14(3), 587-598.

Rasheed Gbolagade A. (2012). Perception of Shea Nut Tree as an Economic Tree among Farmers in Oyo State, Nigeria.

Ryan A, \& Deci RJ. (2010). The Science of subjective well-being. New York: Guilford press.

Sadri Damirchi E, \& Samadifard H. (1398). Predicting of Life Expectancy in Diabetic Patients Based on Self-efficacy, Self-esteem and Perceived Social Support. The Horizon of Medical Sciences, 25(2), 85-92. (In Persian).

Scheffold K, Philipp R, Koranyi S, Engelmann D, Schulz-Kindermann F, Härter M, \& Mehnert A. (2018). Insecure attachment predicts depression and death anxiety in advanced 
cancer patients. Palliative \& supportive care, 16(3), 308-316.

Sherer M, Maddux JE, Mercandante B, Prentice-Dunn S, Jacobs B, \& Rogers RW. (1982). The selfefficacy scale: Construction and validation. Psychological reports, 51(2), 663-671.

Sherman DW, Norman R, \& McSherry CB. (2010). A comparison of death anxiety and quality of life of patients with advanced cancer or AIDS and their family caregivers. Joumal of the Association of Nurses in AIDS Care, 21(2), 99-112.

Templer DI. (1970). The construction and validation of a death anxiety scale. The Joumal of general psychology, 82(2), 165-177.

Zaman B, Hemati K, Hasani V, Dariaie P, \& Faezipour H. (2009). Comparison of the Efficacy of Transdermal Fentanyl in the Treatment of Chronic Soft Tissue Cancer Pain with Placebo in a Double Blind Randomized Clinical Trial. Razi Joumal of Medical Sciences, 16, 0-10. (In persian). 